\title{
Selection of Extended Products in Cross Type Extension Based on Fuzzy Grey Relational Clustering Analysis
}

\author{
Su-Zhou WANG ${ }^{1, a,{ }^{*}}$ \\ ${ }^{1}$ School of Business, GanNan Normal University, Ganzhou, China \\ azxrwszzly@sina.com \\ ${ }^{*}$ Corresponding author
}

\begin{abstract}
Key words: Cross type extension, Extended product, Fuzzy comprehensive evaluation method, Grey relational clustering analysis
\end{abstract}

\begin{abstract}
Considering that the selection of extended products in cross type extension is influenced by much of uncertain or fuzzy information, a new quantitative evaluation model, namely comprehensive evaluation model of selection of extended products in cross type extension is established by combining fuzzy comprehensive evaluation method with grey relational clustering analysis theory based on constructing the evaluation index system of cross-class extended products selection. The good or bad of extended products schemes is evaluated according to the grey relational clustering value and the maximum correlation degree. The application result of the model in the case of Haier brand extension is consistent with the actual situation.
\end{abstract}

\section{Introduction}

There are two kinds of running program of brand extension: One is to have brand first, then to find the right product, its purpose is to brand equity and it is due to the need for brand to extend, the other is to have the product first, and then to make the new product enter the market better and faster by the light of the strong brand, the main benefits is the product rather than the brand, and it is due to the need for product to enter the market. ${ }^{[1]}$ The second case is not for the sake of strategy for brand extension, and it is a short-term behavior to the enterprise. Therefore, we mainly discuss about the first kind. Brand extension can be divided into two categories, one is cross type extension, and the other is inline extension. ${ }^{[2]}$ Obviously, the risk of cross type extension is greater than inline extension when you select the appropriate extended products. Nowadays, brand extension is widely used in many enterprises, including failures, and the main reason for the failure is the fault of selection extended products. Therefore, research on the selection of extended products in cross type extension has important practical significance.

Selection of extended products in cross type extension is affected by uncertainty or fuzzy factors, so the essence of extended product selection is a complex multiple attribute decision problem. So a comprehensive evaluation model is established in this paper. In this model, first to obscure the data source by using fuzzy mathematics, then to analyze the data by using fuzzy grey correlation clustering, and finally to discharge pros, so as to select the ideal extended product.

\section{Construct Evaluation Index System of Selecting Extended Products in Cross Type Extension}

The brand will have the foundation to extend successful when its equity accumulates to a certain degree. The condition and the guarantee of brand extension successful is the similarity between the original brand and new extended product as well as the extended product's operation successful. 
${ }^{[3]}$ So we construct an evaluation index system of selection extended products in cross type extension ${ }^{[4-7]}$, as shown in Table 1.

Table 1 Evaluation index system of selecting extended products in cross type extension

\begin{tabular}{|c|c|c|}
\hline Level in & Secondary indicators & Indicators \\
\hline \multirow{4}{*}{$\begin{array}{l}\text { Similarity } \\
\text { between the } \\
\text { extended products } \\
\text { and the original } \\
\text { brand product }\left(\mathrm{B}_{1}\right)\end{array}$} & $\begin{array}{l}\text { Audiences similarity } \\
\qquad\left(\mathrm{C}_{11}\right)\end{array}$ & $\begin{array}{l}\text { Consumers' characteristics proximity between } \\
\text { extended products and original brand products }\end{array}$ \\
\hline & $\begin{array}{l}\text { Technical similarity } \\
\left(\mathrm{C}_{12}\right)\end{array}$ & $\begin{array}{l}\text { The core technology of original brand products can } \\
\text { be transferred to the extended manufacturing degree }\end{array}$ \\
\hline & $\begin{array}{l}\text { Complementary } \\
\qquad\left(\mathrm{C}_{13}\right)\end{array}$ & $\begin{array}{l}\text { The level that belongs to similar product category } \\
\text { between extended products and original brand } \\
\text { products in use }\end{array}$ \\
\hline & $\left(\mathrm{C}_{14}\right)$ & $\begin{array}{l}\text { Extended product can replace the original one, and } \\
\text { provide consumers more delivered value }\end{array}$ \\
\hline \multirow{2}{*}{$\begin{array}{l}\text { Amalgamation } \\
\text { between the } \\
\text { extended products } \\
\text { and the core } \\
\text { brand }\left(\mathrm{B}_{2}\right)\end{array}$} & $\begin{array}{c}\text { Compatibi } \\
\left(\mathrm{C}_{21}\right) \\
\end{array}$ & $\begin{array}{l}\text { The compatibility about the meaning and } \\
\text { association of extended product and brand }\end{array}$ \\
\hline & $\begin{array}{l}\text { Coexistence } \\
\qquad\left(\mathrm{C}_{22}\right)\end{array}$ & $\begin{array}{l}\text { The degree of harmony about extended product } \\
\text { sharing the brand name with the original brand }\end{array}$ \\
\hline \multirow{3}{*}{$\begin{array}{l}\text { Market } \\
\text { characteristics } \\
\text { of the extended } \\
\text { products } \\
\left(\mathrm{B}_{3}\right)\end{array}$} & $\begin{array}{l}\text { Market capacity } \\
\qquad\left(\mathrm{C}_{31}\right)\end{array}$ & $\begin{array}{l}\text { The market demand of extended product, the } \\
\text { greater the demand, the better extension }\end{array}$ \\
\hline & $\begin{array}{l}\text { Market saturation } \\
\left(\mathrm{C}_{32}\right) \\
\end{array}$ & $\begin{array}{l}\text { The market saturation of extended product, the } \\
\text { more unsaturated, the better extension }\end{array}$ \\
\hline & $\begin{array}{l}\text { Market growth } \\
\quad\left(\mathrm{C}_{33}\right)\end{array}$ & $\begin{array}{l}\text { At the state of suggested budgeting or growth in } \\
\text { product life cycle }\end{array}$ \\
\hline \multirow{2}{*}{$\begin{array}{l}\text { Competitive } \\
\text { characteristics of } \\
\text { the extended } \\
\text { products } \\
\left(\mathrm{B}_{4}\right)\end{array}$} & $\begin{array}{l}\text { Brand strength } \\
\left(\mathrm{C}_{41}\right)\end{array}$ & $\begin{array}{l}\text { There are well-known brands or not in extended } \\
\text { industry, the less brand power, the better extension }\end{array}$ \\
\hline & $\begin{array}{l}\text { Competition degree } \\
\qquad\left(\mathrm{C}_{42}\right)\end{array}$ & $\begin{array}{l}\text { The quantity and quality of peer companies, the } \\
\text { lower competition, the better extension }\end{array}$ \\
\hline
\end{tabular}

\section{Construct Comprehensive Evaluation Model of Selection Extending Products in Cross Type Extension}

The basic idea of grey relational analysis is to judge whether the contact closely according to the similarity of the sequence curve geometric shapes. The closer the curve, the greater the correlation between corresponding sequences. Grey relational cluster is based on grey relational analysis, and to cluster according to the recognition principle of maximum correlation. Fuzzy grey correlation clustering analysis is to regard the fuzzy comprehensive evaluation results matrix of evaluation objects as comparative sequences, to calculate correlation between each comparative sequence and each reference sequence, and to cluster according to the size of correlation, thus to discharge pros for each evaluation object. ${ }^{[8]}$ The specific steps of fuzzy grey correlation clustering analysis and evaluation on selecting extending products in cross type extension are as follows: 
Step 1: Determine the fuzzy comprehensive evaluation matrix of Secondary evaluation index

(1) Let $B=\left(B_{1}, B_{2}, \ldots, B_{m}\right)$ to be the factors set made up of level indicators in evaluation index system of selecting extended products, $\mathrm{W}=\left(\mathrm{W}_{1}, \mathrm{~W}_{2}, \ldots, \mathrm{W}_{\mathrm{m}}\right)$ is a weight set represented the weight of $\mathrm{B}_{\mathrm{i}}$ in $\mathrm{B}$, and $\mathrm{W}_{\mathrm{i}} \geq 0(\mathrm{i}=1,2, \ldots, \mathrm{m}), \sum_{i=1}^{m} \mathrm{~W}_{\mathrm{i}}=1$ [9]

(2) Let $\mathrm{C}_{\mathrm{i}}=\left(\mathrm{C}_{\mathrm{i} 1}, \mathrm{C}_{\mathrm{i} 2}, \ldots, \mathrm{C}_{\mathrm{ir}}\right)(\mathrm{i}=1,2, \ldots, \mathrm{m})$ to be the factors set made up of secondary indicators in evaluation index system of selecting extended products, $\mathrm{W}_{\mathrm{i}}=\left(\mathrm{W}_{\mathrm{i} 1}, \mathrm{~W}_{\mathrm{i} 2}, \ldots, \mathrm{W}_{\mathrm{ir}}\right)$ is a weight set represented the weight of $\mathrm{C}_{\mathrm{ij}}$ in $\mathrm{C}_{\mathrm{i}}$, and $\mathrm{W}_{\mathrm{ij}} \geq 0(\mathrm{j}=1,2, \ldots, \mathrm{r}), \sum_{j=1}^{r} \mathrm{~W}_{\mathrm{ij}}=1$ [9]

(3) Determine the weight of $\mathrm{W}_{\mathrm{i}}$ and $\mathrm{W}_{\mathrm{ij}}$ through the method of expert investigation and analytic hierarchy process.

(4) Determine the intensity of performance of each extension product factors to be $U=\left[U_{1}, U_{2}\right.$, $\mathrm{U}_{3}, \mathrm{U}_{4}, \mathrm{U}_{5}$ ], and $\mathrm{U}=$ [Better, Good, Normal, Bad, Worse].

(5) Comprehensive evaluate the factors set of $\mathrm{Ci}(\mathrm{i}=1,2, \ldots, \mathrm{m})$ made up of secondary indicators, and the evaluation steps are as follows ${ }^{[9]}$ :

First, to judge each factor of $C_{i j}(i=1,2, \ldots, m, j=1,2, \ldots, r)$ in $C_{i}$, and obtain the membership named $\mathrm{P}_{\mathrm{ijk}}$ of each factor corresponding to the number $\mathrm{k}$ level evaluation $\left(\mathrm{j}=1,2, \ldots, \mathrm{r} ; \mathrm{k}=1,2,3,4,5, \mathrm{P}_{\mathrm{ijk}}=\mathrm{d}_{\mathrm{ijk}}\right.$ $/ \mathrm{d}$, and $\mathrm{d}$ is the total number of expert group, $\mathrm{d}_{\mathrm{ijk}}$ is the number of experts to make a number $\mathrm{K}$ grade evaluations for the number $j$ evaluation factors in $C_{i}$ ), thus obtain a fuzzy matrix named $R_{i}$ as follows $^{[9]}$ :

$$
\mathrm{R}_{\mathrm{i}}=\left[\begin{array}{ccccc}
\mathrm{P}_{\mathrm{i} 11} & \mathrm{P}_{\mathrm{i} 12} & \mathrm{P}_{\mathrm{i} 13} & \mathrm{P}_{\mathrm{i} 14} & \mathrm{P}_{\mathrm{i} 15} \\
\mathrm{P}_{\mathrm{i} 21} & \mathrm{P}_{\mathrm{i} 22} & \mathrm{P}_{\mathrm{i} 23} & \mathrm{P}_{\mathrm{i} 24} & \mathrm{P}_{\mathrm{i} 25} \\
\ldots & \ldots & \ldots & \ldots & \ldots \\
\mathrm{P}_{\mathrm{ir} 1} & \mathrm{P}_{\mathrm{ir} 2} & \mathrm{P}_{\mathrm{ir} 3} & \mathrm{P}_{\mathrm{ir} 4} & \mathrm{P}_{\mathrm{ir} 5}
\end{array}\right]
$$

Then, to calculate evaluation results matrix named $\mathrm{Y}_{\mathrm{i}}\left(\mathrm{Y}_{\mathrm{i}}=\mathrm{W}_{\mathrm{i}} \bullet \mathrm{R}_{\mathrm{i}}\right)$ for each group by using the calculation of fuzzy matrix synthesis. ${ }^{[9]}$

Step 2: Structure comparative sequence and reference sequence

Comparative sequence is $\mathrm{Y}_{\mathrm{i}}$, namely the fuzzy comprehensive evaluation matrix of secondary evaluation index of each evaluation object, if $\mathrm{N}$ is the total number of evaluation objects, then $\mathrm{Y}_{\text {in }}=$ $\left\{Y_{\text {in }}(k) \mid k=1,2,3,4,5, i=1,2, \ldots, m, n=1,2, \ldots N\right\}, Y_{\text {in }}(n=1,2, \ldots N)$ is the fuzzy evaluation matrix corresponding to $\mathrm{C}_{\mathrm{i}}$ of the number $\mathrm{n}$ evaluation object. ${ }^{[10]}$

Because $U=$ [Better, Good, Normal, Bad, Worse], which is divided into five grades, so we construct 5 reference sequences: $\mathrm{Y}_{\mathrm{OP}}=\left\{\mathrm{y}_{\mathrm{op}}(\mathrm{k}) \mid \mathrm{k}=1,2,3,4,5\right\} ; \quad(\mathrm{p}=1,2,3,4,5)$. When $\mathrm{p}=\mathrm{k}$, Yop $(\mathrm{k})=1$, when $\mathrm{p} \neq \mathrm{k}$, Yop $(\mathrm{k})=0 .{ }^{[10]}$

Step 3: Calculate correlation coefficient

The calculation formula for correlation coefficient is as follows:

$$
\xi_{i n p}(k)=\frac{\min _{n}\left[\min _{k} \Delta n(k)\right]+\rho \max _{n}\left[\max _{k} \Delta n(k)\right]}{\Delta n(k)+\rho \max _{n}\left[\max _{k} \Delta n(k)\right]}
$$


Among them, $\Delta n(k)=\left|y_{0 p}(k)-y_{\text {in }}(k)\right|, \rho$ is the distinguishing coefficient, and its interval is $[0,1]$, normally $\rho=0.5, \xi_{i n p}(k)$ is the correlation coefficient between the $\mathrm{C}_{\mathrm{i}}$ of the number $\mathrm{n}$ evaluation object corresponding to the membership of the number $\mathrm{k}$ level evaluation with the membership of the number $\mathrm{k}$ level evaluation of the number $\mathrm{p}$ reference sequence. ${ }^{[10]} \xi_{\text {inp }}(k)$ is the correlation coefficient between the $C_{i}$ of the number $n$ evaluation object with the number $p$ reference sequence.

$$
\xi_{i n p}=\frac{\xi_{i n p}(1)+\xi_{i n p}(2)+\xi_{i n p}(3)+\xi_{i n p}(4)+\xi_{i n p}(5)}{5}
$$

$\mathrm{Z}_{\text {in }}$ is the correlation coefficient matrix corresponding to $\mathrm{C}_{\mathrm{i}}$ of the number $\mathrm{n}$ evaluation object.

$$
\mathrm{Z}_{\mathrm{in}}=\left[\boldsymbol{\xi}_{\mathrm{in} 1}, \boldsymbol{\xi}_{\mathrm{in} 2}, \boldsymbol{\xi}_{\mathrm{in} 3}, \boldsymbol{\xi}_{\mathrm{in} 4}, \boldsymbol{\xi}_{\mathrm{in} 5}\right]
$$

Let $\mathrm{Z}=\left[\mathrm{Z}_{1 \mathrm{n}}, \mathrm{Z}_{2 \mathrm{n}}, \ldots \mathrm{Z}_{\mathrm{mn}}\right]^{\mathrm{T}}$, $\mathrm{P}$ is the final correlation coefficient matrix of the number $\mathrm{n}$ evaluation object. [10]

$$
\mathrm{P}=\mathrm{W} \cdots \bullet \mathrm{Z}=\left[\mathrm{P}_{\mathrm{n} 1}, \mathrm{P}_{\mathrm{n} 2}, \mathrm{P}_{\mathrm{n} 3}, \mathrm{P}_{\mathrm{n} 4}, \mathrm{P}_{\mathrm{n} 5}\right]
$$

\section{Step 4: Determine the maximum correlation and the grey relational cluster value}

Determine the maximum correlation and the grey relational cluster value according to the final correlation between each evaluation object with each reference sequence. ${ }^{[10]}$

$$
\mathrm{P}_{\mathrm{n}}{ }^{*}=\max \left(\mathrm{P}_{\mathrm{n} 1}, \mathrm{P}_{\mathrm{n} 2}, \mathrm{P}_{\mathrm{n} 3}, \mathrm{P}_{\mathrm{n} 4}, \mathrm{P}_{\mathrm{n} 5}\right)
$$

Among them, $\mathrm{P}_{\mathrm{n}} *$ is the maximum correlation of the number $\mathrm{n}$ evaluation object, and $\mathrm{Tn} *$ is the grey relational cluster value which is the number of the reference sequence . [10]Therefore, the correlation between the number $\mathrm{n}$ evaluation object with the number $\mathrm{Tn} *$ reference sequence is the largest, and its similarity is the highest.

Step 5: Sort the evaluation objects

First, to sort the evaluation object according to the grey relational cluster value $\mathrm{Tj}^{*}$ from small to large, then, to sort the evaluation objects which have the same grey relational cluster value according to the principle of maximum correlation $\mathrm{Pj}^{*}$ from large to small, thus to sort all evaluation objects. ${ }^{[10]}$

\section{The Specific Application of Evaluation Model}

We take the case of Haier brand extension for empirical analysis on the evaluation model. And the evaluation index set is shown in Table 1.

Determine the weight by expert investigation method, and the weight of evaluation indexes are as follows: $\mathrm{W}=(0.2733,0.2400,0.2800,0.2067), \mathrm{W}_{1}=(0.3133,0.2933,0.2200,0.1733), \mathrm{W}_{2}=(0.4667$, $0.5333), \mathrm{W}_{3}=(0.3333,0.3000,0.3667), \mathrm{W}_{4}=(0.5267,0.4733)$. 
Comment set $\mathrm{U}=\{$ Better, Good, Normal, Bad, Worse $\}$

Take alternative extended products as evaluation objects. Because it is to validate the model after the event, we take the six kinds of product or industry which haier has extended to from 1992 to 1999 as evaluation objects. That is $\mathrm{N}_{1}=$ Air-condition, $\mathrm{N}_{2}=$ Washer, $\mathrm{N}_{3}=$ Medicine, $\mathrm{N}_{4}=$ Color TV, $\mathrm{N}_{5}=$ Computer, $\mathrm{N}_{6}=$ Phone.

Using expert (15 people) in the form of questionnaire survey to collect the evaluation data, statistical sorting after withdrawing questionnaire, and calculate the evaluation matrix of each factor of $\mathrm{C}_{\mathrm{i}}$, as shown in Table 2 .

Table 2 Evaluation results of $\mathrm{C}_{\mathrm{i}}$ of each extended product

\begin{tabular}{|c|c|c|c|c|c|c|c|c|c|c|}
\hline \multirow{2}{*}{$\begin{array}{l}\text { Extended } \\
\text { products } \\
\text { Air-condition }\end{array}$} & \multicolumn{2}{|c|}{$\begin{array}{l}\text { Similarity between } \\
\text { brand products }\left(B_{1}\right)\end{array}$} & \multicolumn{3}{|c|}{ extended products and original } & \multicolumn{5}{|c|}{$\begin{array}{l}\text { Amalgamation between extended products and core } \\
\text { brand }\left(B_{2}\right)\end{array}$} \\
\hline & {$[0.3124$} & 0.4746 & 0.1142 & 0.0755 & $0.0231]$ & {$[0.4755$} & 0.4311 & 0.0933 & 0.0000 & $0.0000]$ \\
\hline Washer & {$[0.2133$} & 0.3724 & 0.2715 & 0.0964 & $0.0462]$ & {$[0.2711$} & 0.4711 & 0.1956 & 0.0622 & $0.0000]$ \\
\hline Medicine & {$[0.0000$} & 0.0000 & 0.0325 & 0.2640 & $0.7035]$ & {$[0.0000$} & 0.0000 & 0.0000 & 0.3067 & $0.6933]$ \\
\hline Color TV & {$[0.0209$} & 0.1133 & 0.4204 & 0.3680 & $0.0773]$ & {$[0.0356$} & 0.1689 & 0.4978 & 0.2978 & $0.0000]$ \\
\hline Computer & {$[0.0418$} & 0.3355 & 0.3769 & 0.1995 & $0.0462]$ & {$[0.2044$} & 0.4356 & 0.3600 & 0.0000 & $0.0000]$ \\
\hline Phone & {$[0.0209$} & 0.0533 & 0.3840 & 0.4088 & $0.1329]$ & {$[0.0356$} & 0.2044 & 0.3644 & 0.3956 & $0.0000]$ \\
\hline
\end{tabular}

Table 2 Evaluation results of $\mathrm{C}_{\mathrm{i}}$ of each extended product (continue)

\begin{tabular}{|c|c|c|c|c|c|c|c|c|c|c|}
\hline \multirow{2}{*}{$\begin{array}{l}\begin{array}{l}\text { Extended } \\
\text { products }\end{array} \\
\text { Air-condition }\end{array}$} & \multicolumn{5}{|c|}{ Market characteristics of extended products ( $B_{3}$ ) } & \multicolumn{4}{|c|}{$\begin{array}{l}\text { Competitive } \\
\text { products }\left(B_{4}\right)\end{array}$} & \multirow[t]{2}{*}{ extended } \\
\hline & {$[0.5422$} & 0.3244 & 0.0911 & 0.0200 & $0.0222]$ & {$[0.2316$} & 0.3964 & 0.2386 & 0.1333 & \\
\hline Washer & {$[0.2934$} & 0.5155 & 0.1489 & 0.0422 & $0.0000]$ & {$[0.0316$} & 0.3262 & 0.4738 & 0.1684 & $0.0000]$ \\
\hline Medicine & {$[0.1066$} & 0.2289 & 0.3533 & 0.2178 & $0.0934]$ & {$[0.1053$} & 0.0316 & 0.2631 & 0.4982 & $0.1018]$ \\
\hline Color TV & {$[0.1555$} & 0.5067 & 0.2511 & 0.0867 & $0.0000]$ & {$[0.0000$} & 0.0947 & 0.4982 & 0.2702 & 0.1369 ] \\
\hline Computer & {$[0.1156$} & 0.4000 & 0.3400 & 0.1244 & $0.0200]$ & {$[0.0667$} & 0.0316 & 0.3018 & 0.4631 & $0.1369]$ \\
\hline Phone & {$[0.1555$} & 0.4867 & 0.1556 & 0.1822 & $0.0200]$ & {$[0.0000$} & 0.0982 & 0.2631 & 0.3964 & $0.2422]$ \\
\hline
\end{tabular}

Calculate correlation coefficient matrix for each factor of $\mathrm{C}_{\mathrm{i}}$ according to the model, as shown in Table 3.

Table 3 Correlation coefficient matrix of $\mathrm{C}_{\mathrm{i}}$ of each extended product

\begin{tabular}{|c|c|c|c|c|c|c|c|c|c|c|}
\hline \multirow{2}{*}{$\begin{array}{l}\begin{array}{l}\text { Extended } \\
\text { products }\end{array} \\
\text { Air-condition }\end{array}$} & \multicolumn{2}{|c|}{$\begin{array}{l}\text { Similarity between } \\
\text { brand products }\left(B_{1}\right)\end{array}$} & \multicolumn{3}{|c|}{ a extended products and original } & \multicolumn{2}{|c|}{$\begin{array}{l}\text { Amalgamation } \\
\text { core brand }\left(B_{2}\right)\end{array}$} & \multirow{2}{*}{$\begin{array}{l}\text { between } \\
50.6810\end{array}$} & \multirow{2}{*}{$\begin{array}{c}\text { extended } \\
0.6451\end{array}$} & \multirow{2}{*}{$\begin{array}{l}\text { d products } \\
0.6451]\end{array}$} \\
\hline & {$[0.7146$} & 0.7484 & 0.6570 & 0.6356 & $0.6254]$ & {$[0.7736$} & 0.7646 & & & \\
\hline Washer & {$[0.6727$} & 0.7093 & 0.6809 & 0.6231 & $0.6160]$ & {$[0.7060$} & 0.7485 & 0.6872 & 0.6460 & $0.6210]$ \\
\hline Medicine & {$[0.6684$} & 0.6684 & 0.6775 & 0.7433 & $0.8418]$ & {$[0.6744$} & 0.6744 & 0.6744 & 0.7676 & 0.8479] \\
\hline Color TV & {$[0.6277$} & 0.6612 & 0.7308 & 0.7126 & $0.6449]$ & {$[0.6434$} & 0.6874 & 0.7613 & 0.7196 & $0.6284]$ \\
\hline Computer & {$[0.6283$} & 0.7105 & 0.7138 & 0.6645 & $0.6254]$ & {$[0.7003$} & 0.7522 & 0.7366 & 0.6318 & $0.6318]$ \\
\hline Phone & {$[0.6295$} & 0.6423 & 0.7251 & 0.7230 & $0.6650]$ & {$[0.6376$} & 0.6912 & 0.7284 & $4 \quad 0.7349$ & $0.6227]$ \\
\hline
\end{tabular}


Table 3 Correlation coefficient matrix of $\mathrm{C}_{\mathrm{i}}$ of each extended product (continue)

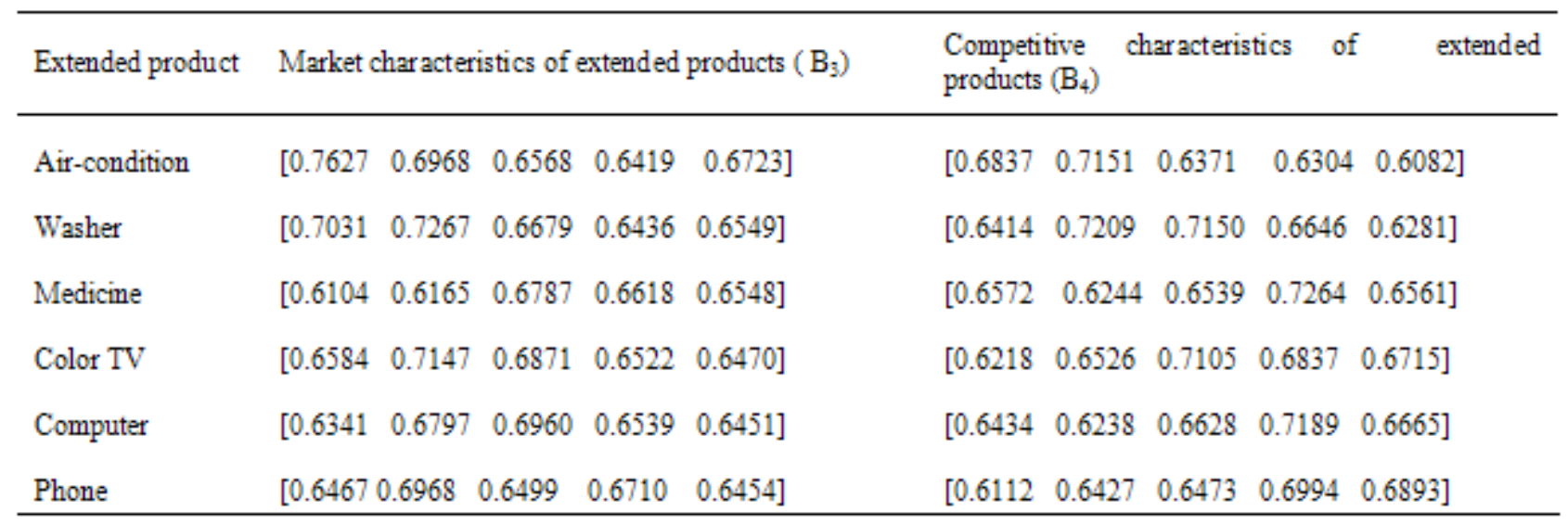

Calculate the final correlation coefficient matrix for each extended product according to the above model, as shown in Table 4

Table 4 Final correlation coefficient matrix of each extended product

\begin{tabular}{|c|c|c|c|c|c|}
\hline \multirow{2}{*}{$\begin{array}{l}\text { Extended product } \\
\text { Air-condition }\end{array}$} & \multicolumn{5}{|c|}{ Final correlation coefficient matrix } \\
\hline & {$[0.7358$} & 0.7310 & 0.6586 & 0.6386 & $0.6397]$ \\
\hline Washer & {$[0.6827$} & 0.7260 & 0.6858 & 0.6429 & $0.6306]$ \\
\hline Medicine & {$[0.6513$} & 0.6462 & 0.6722 & 0.7228 & $0.7525]$ \\
\hline Color TV & {$[0.6388$} & 0.6807 & 0.7217 & 0.6914 & 0.6470] \\
\hline Computer & {$[0.6503$} & 0.6940 & 0.7037 & 0.6649 & 0.6409] \\
\hline Phone & {$[0.6325$} & 0.6694 & 0.6888 & 0.7064 & $0.6544]$ \\
\hline
\end{tabular}

Determine the maximum correlation and grey relation clustering value of each extended product according to the final correlation coefficient matrix, and thus determine the sort of each extended product, as shown in Table 5.

Table 5 Maximum correlation, grey relation clustering value and sort of each extended product

\begin{tabular}{lccc}
\hline Extended products & Maximum correlation & Grey relational cluster value & Sort \\
\hline Air-condition & 0.7358 & 1 & 1 \\
Washer & 0.7260 & 2 & 2 \\
Medicine & 0.7525 & 5 & 6 \\
Color TV & 0.7217 & 3 & 3 \\
Computer & 0.7037 & 3 & 4 \\
Phone & 0.7064 & 4 & 5 \\
\hline
\end{tabular}

\section{Conclusions}

In this paper, a multi-level fuzzy grey correlation clustering analysis and evaluation model is built by combining fuzzy comprehensive evaluation method with gray theory, Using the model to comprehensive evaluate the selection of extended products of haier (1992-1999), and its evaluation 
result compared with the market performance of each extended product has good consistency. Therefore, the model is reasonable, effective and with strong feasibility, it will provide new ideas for the selection of extended product scientifically and reasonably.

\section{References}

[1] Yong-gao Song. Brand Strategy and Management [M]. Zhejiang University Press, 2003.

[2] Su-zhou Wang. Research on the Theory and Strategic Management of Brand Extension [D]. Xiangtan University, 2005.

[3] Su-zhou Wang. Analysis on the Successful Factors of Brand Extension: the Enlightenment of Balance Theory [J]. Science Technology and Industry, 2009, 9(1):62-65.

[4] Guo-qun Fu. Study on Brand Extension: Retrospect and Prospect [J]. China Soft Science, 2003, (1):75-81.

[5] Xiang Dong Weng. Seven Iron Law of Brand Extension [J]. Chinese and Foreign Management, 2003, (3):46-48.

[6] Xiang Dong Weng. Local Brand Strategy [M].Nanjing University Press, 2008.

[7] Liu He, Chun Xiao, Jin-ling Lian. Research on Similarity Influence on Brand Extension Evaluation[J]. Soft Science, 2011, 25(5):47-52.

[8] Chun-yu Zhao, Xu-chao Zhang. Research on Supplier Evaluation Based on Rough Sets and Fuzzy Grey Correlation Clustering Analysis[J]. Market Modernization, 2012, (8):20-22.

[9] Ren-jian Deng, Bo-zhi Ren, Jun Chen. Multi-level Fuzzy Grey Correlation Clustering Analysis of Small Sewage Plant Process Selection[J]. China Water \& Wastewater, 2010, 26(11):64-67.

[10] Hui Zhang, De-li Gao. Multi-level Comprehensive Evaluation Method and Its Application Based on the Theory of Fuzzy Mathematics and Gray[J]. Mathematics in Practice and Theory, 2008,38(3):1-6. 